\title{
Hydrogen Peroxide- and Nitric Oxide-mediated Disease Control of Bacterial Wilt in Tomato Plants
}

\author{
Jeum Kyu Hong ${ }^{1 *}$, Su Ran Kang ${ }^{1}$, Yeon Hwa Kim ${ }^{1}$, Dong June Yoon ${ }^{1}$, Do Hoon Kim¹, Hyeon Ji Kim¹, \\ Chang Hyun Sung ${ }^{1 \dagger}$, Han Sol Kang ${ }^{1}$, Chang Won Choi ${ }^{2}$, Seong Hwan Kim ${ }^{3}$ and Young Shik Kim ${ }^{4}$ \\ ${ }^{1}$ Department of Horticultural Science, Gyeongnam National University of Science and Technology (GNTech), Jinju 660-758, Korea \\ ${ }^{2}$ Department of Biology and Medical Science, Paichai University, Daejeon 302-735, Korea \\ ${ }^{3}$ Department of Microbiology and Institute of Basic Sciences, Dankook University, Cheonan 330-714, Korea \\ ${ }^{4}$ Department of Plant Science and Food Biotechnology, Sangmyung University, Cheonan 330-720, Korea \\ 'Present address: CMC Korea Inc., 828-11 Sangseo-dong, Daejeon 306-120, Korea
}

(Received on April 23, 2013; Revised on August 21, 2013; Accepted on August 23, 2013)

\begin{abstract}
Reactive oxygen species (ROS) generation in tomato plants by Ralstonia solanacearum infection and the role of hydrogen peroxide $\left(\mathrm{H}_{2} \mathrm{O}_{2}\right)$ and nitric oxide in tomato bacterial wilt control were demonstrated. During disease development of tomato bacterial wilt, accumulation of superoxide anion $\left(\mathrm{O}_{2}{ }^{-}\right)$and $\mathrm{H}_{2} \mathrm{O}_{2}$ was observed and lipid peroxidation also occurred in the tomato leaf tissues. High doses of $\mathrm{H}_{2} \mathrm{O}_{2}$ and sodium nitroprusside (SNP) nitric oxide donor showed phytotoxicity to detached tomato leaves 1 day after petiole feeding showing reduced fresh weight. Both $\mathrm{H}_{2} \mathrm{O}_{2}$ and SNP have in vitro antibacterial activities against $R$. solanacearum in a dose-dependent manner, as well as plant protection in detached tomato leaves against bacterial wilt by $10^{6}$ and $10^{7} \mathrm{cfu} / \mathrm{ml}$ of $R$. solanacearum. $\mathrm{H}_{2} \mathrm{O}_{2}$ - and SNP-mediated protection was also evaluated in pots using soil-drench treatment with the bacterial inoculation, and relative 'area under the disease progressive curve (AUDPC)' was calculated to compare disease protection by $\mathrm{H}_{2} \mathrm{O}_{2}$ and/ or SNP with untreated control. Neither $\mathrm{H}_{2} \mathrm{O}_{2}$ nor SNP protect the tomato seedlings from the bacterial wilt, but $\mathrm{H}_{2} \mathrm{O}_{2}+\mathrm{SNP}$ mixture significantly decreased disease severity with reduced relative AUDPC. These results suggest that $\mathrm{H}_{2} \mathrm{O}_{2}$ and SNP could be used together to control bacterial wilt in tomato plants as bactericidal agents.
\end{abstract}

Keywords : antibacterial agents, hydrogen peroxide, nitric oxide, Ralstonia solanacearum, tomato bacterial wilt

Bacterial wilt disease caused by Ralstonia solanacearum occurs in many plant species and leads to destructive and economical damages, especially, in tomato production in tropical, subtropical and warm temperate regions (Hayward,

\footnotetext{
*Corresponding author.

Phone) +82-55-751-3251, FAX) +82-55-751-3257

E-mail)jkhong@gntech.ac.kr
}

1991). To invade and colonize host tissues successfully, soil-borne $R$. solanacearum has developed biochemical weapons; extracellular polysaccharides, cell-wall-degrading enzymes and type III secreted effectors (Macho et al., 2010; Saile et al., 1997; Valls et al., 2006). However, during infection process the bacterium experience reactive oxygen species (ROS) produced in host plants to arrest the bacterial growth (Flores-Cruz and Allen, 2009). Thus, the bacterium should overcome ROS-mediated host defenses by the activation of ROS-scavenging enzymes and the expression of oxidative stress tolerance gene (Colburn-Clifford et al., 2010; Flores-Cruz and Allen, 2011; Loprasert et al., 1996), and lead to compatible interactions between host plants and virulent bacterial strains. Virulence factors originated from $R$. solanacearum have been investigated to understand molecular machinery of the bacterial pathogenesis and to develop efficient disease control strategy in recent decades (Brown and Allen, 2004; Franks et al., 2008; Schell, 2000).

For the disease control of tomato bacterial wilt disease, multidirectional controls including cultural, biological and chemical methods have been applied so far. Chloropicrin was suggested as the most promising chemical for reducing tomato bacterial wilt when it was used as soil fumigant before transplanting (Enfinger et al., 1979). However, it can be irritating and phytotoxic under incomplete vaporization conditions in the treated soil. Antibiotic validamycin A inhibited in vitro growth of $R$. solanacearum and delayed symptom development of tomato bacterial wilt (Ishikawa et al., 1996). Commercial chemical pesticides containing copper hydroxide, copper hydroxide-oxadixyl, copper oxychloridedithianon and streptomycin-validamycin A, delayed tomato bacterial wilt when the bacterial pathogen was inoculated at the same time of pesticide application (Lee et al., 2012). Appearance of pesticide resistance has been concerned although there is no report on the resistance of $R$. solanacearum to antibiotics or chemical pesticides in tomato 
fields. In recent years, soil amendment, essential oils, antagonistic bacteria, plant growth-promoting rhizobacteria (PGPR) and plant defense-activating chemical agents have been tried to control tomato bacterial wilt as environmentally sustainable disease management (Anith et al., 2004; Ji et al., 2005; Nakaune et al., 2012; Nguyen and Ranamukhaarachichi, 2010; Park et al., 2007). More ecofriendly control methods need to be investigated for the integrated management of tomato bacterial wilt.

To minimize damages from pathogen infections, host plants have established sophisticated defense mechanisms including cell wall enforcement, accumulation of pathogenesis-related proteins and accelerated cell death (Deepak et al., 2010; Greenberg et al., 2004; van Loon et al., 2006). Plants can memorize prior pathogen infection and be ready for challenging pathogens. For the establishment of induced and systemic acquired resistance, a variety of plant defense signaling pathways are involved and cross-talked (Grant and Lamb, 2006; Koornneef and Pieterse, 2008; Liu et al., 2011; Pieterse et al., 2009). So far, several small chemicals are known to be de novo synthesized and accumulated during pathogenesis and hypersensitive defense responses in host plants. Salicylic acid, jasmonic acid and ethylene are among most distinguished defense signal molecules, but there is limited information whether these are mobile signals for systemic defense or not. More recently, $\mathrm{H}_{2} \mathrm{O}_{2}$ and nitric oxide have been demonstrated defense signal molecules which play roles in activation of plant resistance against pathogen attacks. $\mathrm{H}_{2} \mathrm{O}_{2}$ mediated plant defense responses by induced resistance against pathogen infection (Byun and Choi, 2004; Hafez et al., 2012). Elevated endogenous nitric oxide level in plants also resulted in enhanced disease resistance against viral, bacterial, oomycete and fungal pathogens (Chun et al., 2012; Fu et al., 2010; Guo et al., 2004).

Relatively high doses of $\mathrm{H}_{2} \mathrm{O}_{2}$ and nitric oxide can exert direct antimicrobial activities to kill microbes including plant pathogens. $\mathrm{H}_{2} \mathrm{O}_{2}$ showed direct antibacterial activity against Xanthomonas campestris pv. vignicola causing cowpea bacterial blight, and pretreatment of cowpea seeds and seedlings with $\mathrm{H}_{2} \mathrm{O}_{2}$ reduced the disease severity (Kotchoni et al., 2007). In vitro germination of sporangiospores of Peronospora tabacina causing tobacco blue mildew was gradually inhibited by increasing $\mathrm{H}_{2} \mathrm{O}_{2}$ concentration exogenously applied (Peng and Kuć, 1992). Endogenous generation of $\mathrm{H}_{2} \mathrm{O}_{2}$ in tobacco leaves mediated by peroxidase and cofactors simultaneous applications in the presence of NADH or NADPH significantly reduced disease severity of tobacco blue mold by P. tabacina infection (Peng and Kuć, 1992). Nitric oxide treatment inhibited in vitro spore germination, sporulation and mycelial growth of Aspergillus niger, Monilinia fructicola and Penicillium italicum, and fruits become rotten by these fungal infection during postharvest storage and marketing (Lazar et al., 2008). In vitro inhibition of spore germination and germ tube elongation was observed in grey mold fungus Botrytis cinerea treated with nitric oxide (Lai et al., 2011). Exogenous nitric oxide treatment of tomato fruits delayed the symptom development by direct antifungal activity as well as by indirectly enhancing resistance (Lai et al., 2011). These findings suggest that $\mathrm{H}_{2} \mathrm{O}_{2}$ and nitric oxide can be prevalently used for disease control including tomato bacterial wilt, although antibacterial activities of $\mathrm{H}_{2} \mathrm{O}_{2}$ and nitric oxide against $R$. solanacearum and phytotoxic effects on tomato plants have not been demonstrated yet. Genetically modified biocontrol bacterium, Pseudomonas fluorescens producing higher content of nitric oxide could confer much stronger disease suppression capability against tomato bacterial wilt (Wang et al., 2005). These studies promoted us to investigate whether $\mathrm{H}_{2} \mathrm{O}_{2}$ and nitric oxide can be applied directly in tomato plants to control bacterial wilt disease caused by $R$. solanacearum.

In this study, accumulation of ROS in tomato leaf tissues during the bacterial pathogenesis was investigated. In vitro antibacterial activity of $\mathrm{H}_{2} \mathrm{O}_{2}$ and nitric oxide, response of tomato plants to both chemicals and disease control of tomato bacterial wilt by these chemicals were evaluated.

\section{Materials and Methods}

Plant growth and bacterial culture. Tomatoes (cv. Cupirang) were raised in commercial soil mixtures in pots $(80 \mathrm{~mm}$ in diameter, $75 \mathrm{~mm}$ in height) in a walk-in growth chamber, where 12-h light illuminated and temperature conditions of day and night were described in previous study (Lee et al., 2012). Four- and five-week-old tomato plants were used for soil drenching and petiole dipping of bacterial inoculation, respectively. $R$. solanacearum strain GMI1000 cultured overnight in TTC ( $1 \%$ peptone, $0.1 \%$ casamino acid, $0.5 \%$ glucose and $0.0005 \%$ 2,3,5-triphenyl tetrazolium chloride broth) at $30^{\circ} \mathrm{C}$ was centrifuged and the bacterial pellet was resuspended (Nakaune et al., 2012). Bacterial cell number in the suspension was adjusted to 0.15 at $\mathrm{OD}_{600 \mathrm{~nm}}$ with a $10^{8}$ $\mathrm{cfu} / \mathrm{ml}$ in sterile water using a spectrophotometer. For in vitro antibacterial activity test of $\mathrm{H}_{2} \mathrm{O}_{2}$ and SNP, $40 \mu \mathrm{l}$ of the bacterial suspension $\left(10^{7}\right.$ or $\left.10^{8} \mathrm{cfu} / \mathrm{ml}\right)$ was added to $4 \mathrm{ml}$ of TTC broth in 15-ml conical tube and incubated with shaking overnight $(17 \pm 0.5 \mathrm{~h}$ duration $)$ at $30^{\circ} \mathrm{C}$. Bacterial growth with or without chemical treatment was indirectly measured spectrophotometically at $\mathrm{OD}_{600 \mathrm{~nm}}$. Relative growth of the bacteria in response to $\mathrm{H}_{2} \mathrm{O}_{2}$ and SNP treatments was expressed as percentage (\%) compared to that of the untreated bacterial culture.

Plant inoculation and disease assessment. For inoculation 
by petiole dipping of tomato leaves, the 3 rd leaves were detached from five-week-old plants and were transferred to $10 \mathrm{ml}$ of the bacterial suspension $\left(10^{6}\right.$ and $\left.10^{7} \mathrm{cfu} / \mathrm{ml}\right)$ in a $50 \mathrm{ml}$ conical tube with or without antibacterial chemical treatment. Fresh weight (FW) of the detached leaves was measured before and after inoculation. Relative FW of the inoculated leaves were expressed for wilting symptom development with loss of FW.

For soil drench inoculation, $10 \mathrm{ml}$ of bacterial suspension $\left(2 \times 10^{8} \mathrm{cfu} / \mathrm{ml}\right)$ was evenly poured into soil mixture in pot (200 $\mathrm{ml}$ in volume) containing four-week-old tomato seedlings to make final bacterial concentration $1 \times 10^{7} \mathrm{cfu} /$ $\mathrm{ml}$ soil mixture. Disease severity was evaluated daily based on disease index and area under disease progress curve (AUDPC) was calculated based on previously described method (Lee et al., 2012).

$\mathrm{H}_{2} \mathrm{O}_{2}$ and nitric oxide treatments. Different concentration of $\mathrm{H}_{2} \mathrm{O}_{2}(0.0005,0.001,0.002,0.005,0.01,0.02,0.05,0.1$ and $0.2 \mathrm{mM})$ and SNP nitric oxide releasing agent $(0.0005$, $0.001,0.002,0.005,0.01,0.02,0.05,0.1,0.2,0.5,1$ and 2 $\mathrm{mM}$ ) was added to the TTC broth at the beginning of the bacterial culture to investigate in vitro growth of $R$. solanacearum in response to both chemicals. For plant protection by these chemicals, $\mathrm{H}_{2} \mathrm{O}_{2}(1,2,5,10,20,50$ and $100 \mathrm{mM})$ and $\operatorname{SNP}(0.001,0.01,0.1,0.2$ and $0.5 \mathrm{mM})$ were added to the bacterial suspension before dipping the detached tomato leaves into the bacterial suspension. For whole seedling assay in pots, $10 \mathrm{ml}$ of $200 \mathrm{mM} \mathrm{H}_{2} \mathrm{O}_{2}$ and/or $10 \mathrm{ml}$ of $4 \mathrm{mM} \mathrm{SNP}$ were soil-drenched into the pots containing four-week-old tomato plants in the $200 \mathrm{ml}$ of soil mixture to make final concentrations of $10 \mathrm{mM}$ of $\mathrm{H}_{2} \mathrm{O}_{2}$ and/or $0.2 \mathrm{mM}$ of SNP in the pots.

Histochemical staining. To observe ROS accumulation and lipid peroxidation of the tomato leaf tissues, different histochemical staining was performed. Superoxide anion $\left(\mathrm{O}_{2}^{-}\right)$accumulation was detected as blue-violet color precipitates when the plant tissues were stained with $0.1 \%$ nitroblue tetrazolium (NBT) prepared in $10 \mathrm{mM}$ of potassium phosphate $(\mathrm{pH} 7.8)$ and $10 \mathrm{mM} \mathrm{NaN}_{3}$ without vacuum infiltration (Bournonville and Díaz-Ricci, 2011). $\mathrm{H}_{2} \mathrm{O}_{2}$ accumulation was visualized as red brown color by floating the leaves on $0.1 \%$ 3,3'-diaminobenzidine (DAB) solution overnight (Thordal-Christensen et al., 1997). Lipid peroxidation was detected in the tomato leaf tissues stained by Schiff's reagent indicating pink color development (Wang and Yang, 2005).

Statistical analyses. Data were analyzed for statistical significance by the SAS (Statistical Analysis System, version 9.1, Cary, NC, USA), and means were compared using
Duncan's multiple range tests. Graphing was conducted with SigmaPlot 10.0 (Systat Software, Inc., San Jose, CA, USA).

\section{Results}

Oxidative stress and lipid peroxidation of detached tomato leaves infected by $\boldsymbol{R}$. solanacearum. We investigated accumulation of ROS and lipid peroxidation during disease progress in tomato plant inoculated by the wiltcausing bacteria $R$. solanacearum, which is known to overcome oxidative stresses from host plants and followed by bacterial proliferation and colonization (Flores-Cruz and Allen, 2009). Tomato leaves infiltrated with the bacterial suspension showed strong $\mathrm{H}_{2} \mathrm{O}_{2}$ accumulation (Flores-Cruz and Allen, 2009). However, R. solanacearum naturally invades host plants through vascular structures of root, stem and leaf veins (Genin, 2010). In this study, we tried to infect tomato plants through petiole-dipping method to investigate accumulation of $\mathrm{O}_{2}^{-}$and $\mathrm{H}_{2} \mathrm{O}_{2}$ in the $R$. solanacearuminoculated tomato leaves (Fig. 1).

To detect histochemically ROS such as $\mathrm{O}_{2}^{-}$and $\mathrm{H}_{2} \mathrm{O}_{2}$ in the tomato tissues, tomato petioles inoculated by petiole dipping were stained with NBT and DAB solutions, respectively. Two different ROS were not generated within 1 day (data not shown) and detected on the infected petioles 3

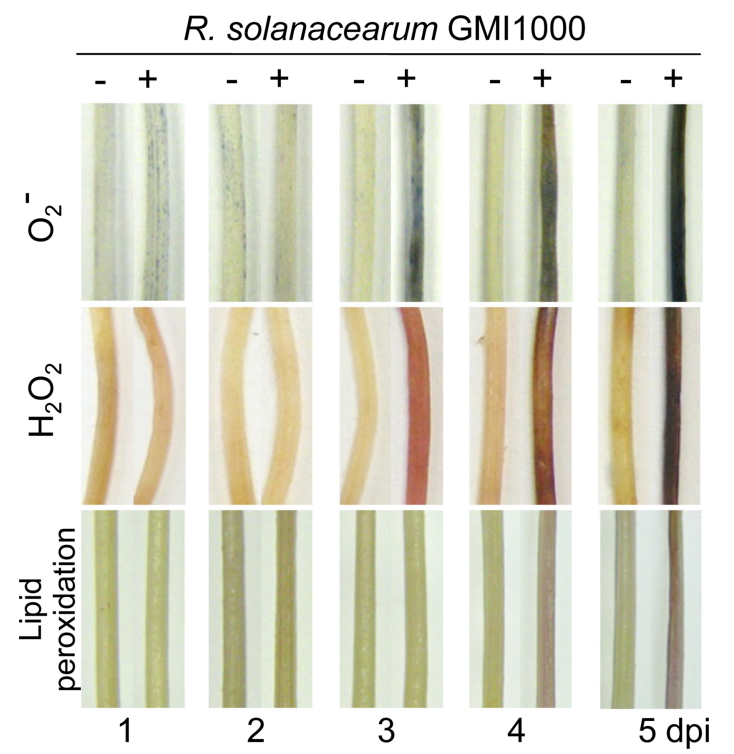

Fig. 1. Accumulation of reactive oxygen species (ROS) and lipid peroxidation in tomato petioles during pathogenesis of Ralstonia solanacearum GMI1000 strain. Superoxide anion $\left(\mathrm{O}_{2}^{-}\right)$(dark blue colored), hydrogen peroxide $\left(\mathrm{H}_{2} \mathrm{O}_{2}\right)$ (red brown colored) and lipid peroxidation (pink colored) in the tomato tissues were histochemically detected by stainings with NBT, DAB and Schiff's reagent, respectively. -, mock-inoculated; +, inoculated. dpi, days post-inoculation. 
A
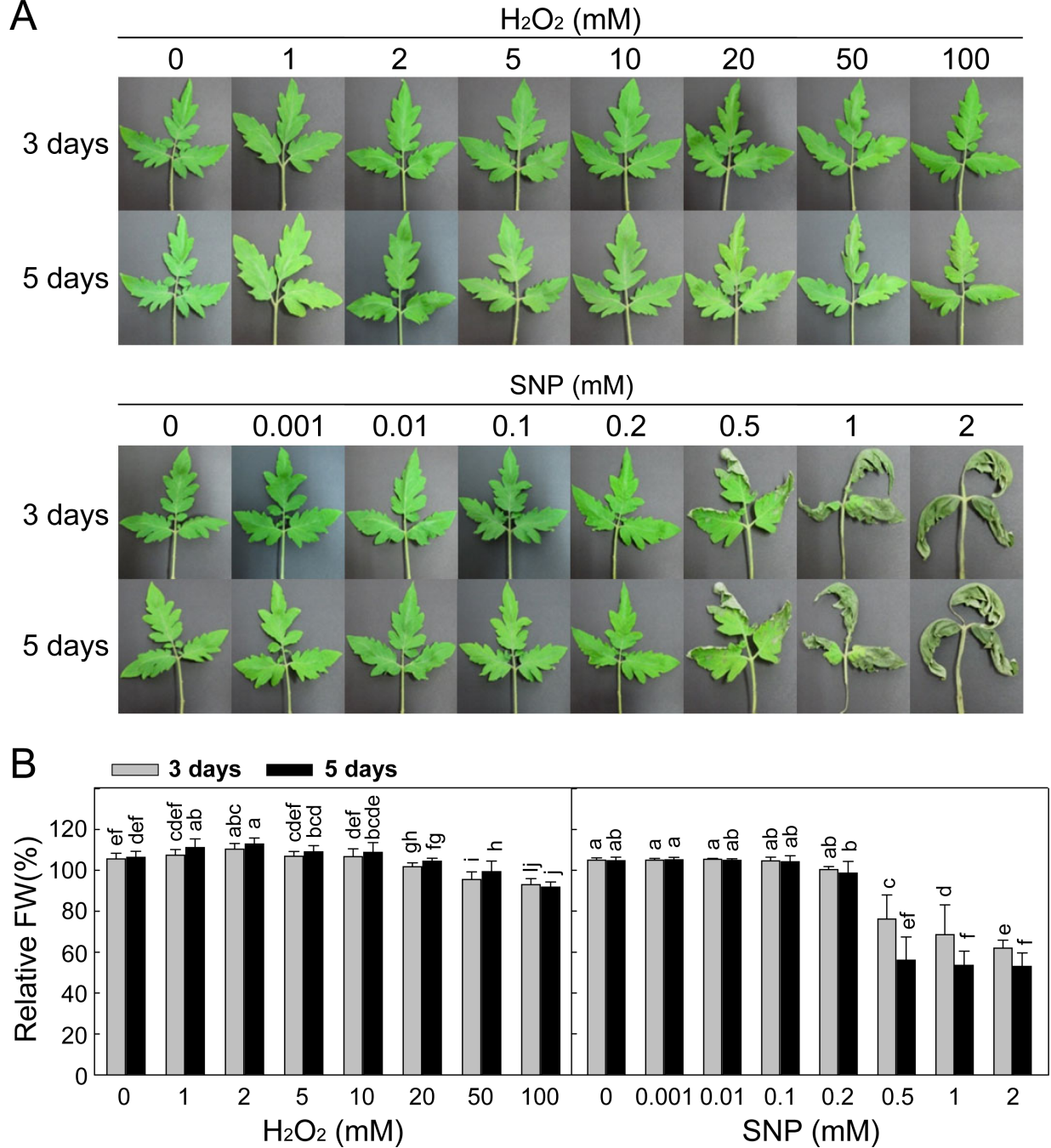

Fig. 2. Effect of $\mathrm{H}_{2} \mathrm{O}_{2}$ and sodium nitroprusside (SNP) nitric oxide releaser on the growth of detached tomato leaves. (A) Different responses of the tomato leaves to $\mathrm{H}_{2} \mathrm{O}_{2}$ and SNP treatments. Photos were taken at 3 and 5 days after petiole dipping in the different concentrations of $\mathrm{H}_{2} \mathrm{O}_{2}$ and SNP. (B) Relative fresh weight $(\mathrm{FW})$ of detached tomato leaves treated with different concentrations of $\mathrm{H}_{2} \mathrm{O}_{2}$ and SNP treatments by petiole dipping at 3 and 5 days. Independent experiments were performed 4 times with similar results. The data points are the mean FW \pm standard errors. Mean separation by Duncan's multiple range test at $P=0.05$. The same letter above bars represented no significant difference between treatments.

days after bacterial inoculation, at which leaves began to wilt and petioles still remained normal without lipid peroxidation (Fig. 1). The infected petiole tissues were collapsed after 4-5 days after inoculation. Accumulation of $\mathrm{O}_{2}{ }^{-}$and $\mathrm{H}_{2} \mathrm{O}_{2}$ and lipid peroxidation were more distinguished as shown by strong color development by NBT and DAB.

\section{Response of tomato leaves by $\mathrm{H}_{2} \mathrm{O}_{2}$ and SNP treatments.} Detached tomato leaves were treated with $\mathrm{H}_{2} \mathrm{O}_{2}$ and SNP by petiole feeding, and loss of FW was evaluated whether these chemicals caused phytotoxic damages on the tomato leaves (Fig. 2). Notable tissue damage was not observed in the detached tomato leaves by the whole range of $\mathrm{H}_{2} \mathrm{O}_{2}$ concentrations $(1-100 \mathrm{mM})$ at 3 and 5 days after treatment
(Fig. 2A). By 0.001 to $0.2 \mathrm{mM}$ of SNP treatment, no distinct visible change was found in the detached tomato leaves at 3 and 5 days after treatment. More than $0.5 \mathrm{mM}$ of SNP caused drastic collapse of leaf tissues. Growth of the detached leaves was demonstrated by measuring $\mathrm{FW}$ after $\mathrm{H}_{2} \mathrm{O}_{2}$ and SNP treatments (Fig. 2B). After 3 days, $2 \mathrm{mM}$ of $\mathrm{H}_{2} \mathrm{O}_{2}$ slightly increased $\mathrm{FW}$ and the $\mathrm{FW}$ returned to near value of the normal by $5-10 \mathrm{mM}$ of $\mathrm{H}_{2} \mathrm{O}_{2}$. Higher dose of $\mathrm{H}_{2} \mathrm{O}_{2}(20-100 \mathrm{mM})$ gradually decreased the $\mathrm{FW}$ to ca. $93.0 \%$. At 5 days, the leaf FW was slightly increased by $2-$ $5 \mathrm{mM}$ of low $\mathrm{H}_{2} \mathrm{O}_{2}$ but $5-20 \mathrm{mM}$ was not effective to modulate the growth. Much higher doses of $\mathrm{H}_{2} \mathrm{O}_{2}(50-100$ $\mathrm{mM}$ ) limited the tomato leaf growth to ca. $91.8 \%$. SNP application significantly reduced $\mathrm{FW}$ at 3 and 5 days. 
A
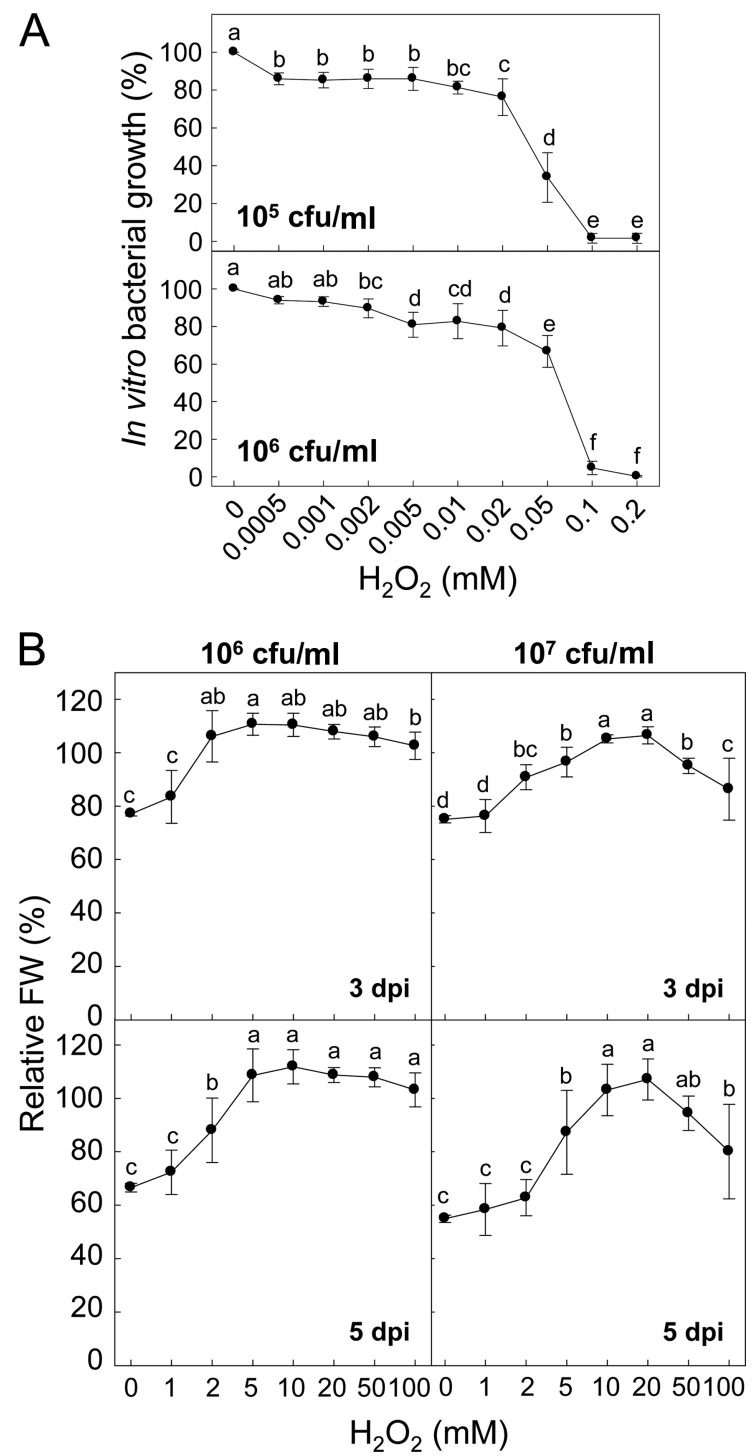

Fig. 3. Effect of $\mathrm{H}_{2} \mathrm{O}_{2}$ on Ralstonia solanacearum growth and bacterial wilt disease of detached tomato leaves. (A) In vitro bacterial growth of $R$. solanacearum in liquid cultures supplemented with different concentration of $\mathrm{H}_{2} \mathrm{O}_{2}$. Initial inoculum doses for the bacterial cultures were shown in upper $\left(10^{5} \mathrm{cfu} / \mathrm{ml}\right)$ and lower $\left(10^{6} \mathrm{cfu} / \mathrm{ml}\right)$ graphs. Relative bacterial growth in response to $\mathrm{H}_{2} \mathrm{O}_{2}$ treatment was demonstrated as percentage (\%) compared to that in untreated bacterial culture. (B) Relative fresh weight $(\mathrm{FW})$ of detached tomato leaves inoculated with two different $R$. solanacearum doses $\left(10^{6}\right.$ and $\left.10^{7} \mathrm{cfu} / \mathrm{ml}\right)$ in the absence or presence of $\mathrm{H}_{2} \mathrm{O}_{2}$ at 3 and 5 days post-inoculation (dpi). Independent experiments were performed 4 times with similar results. The data points are the mean $\mathrm{FW} \pm$ standard errors. Mean separation by Duncan's multiple range test at $P=$ 0.05 . The same letter above bars represented no significant difference between treatments.

Treatment with $0.5 \mathrm{mM}$ began to decrease $\mathrm{FW}$ to ca. $76.1 \%$ compared to that of untreated control. SNP (1 and $2 \mathrm{mM})$ much reduced ca. 68.5 and $62.0 \%$, respectively. At 5 days, drastically decreased FW by $0.5 \mathrm{mM}$ to ca. $56.0 \%$ remained when 1 and $2 \mathrm{mM}$ of SNP were treated.

The effect of $\mathrm{H}_{2} \mathrm{O}_{2}$ on $R$. solanacearum growth in vitro and tomato bacterial wilt control. $\mathrm{H}_{2} \mathrm{O}_{2}$ has been suggested as an antibacterial agent against animal and foodassociated microbes (Cerioni et al., 2009; Larsen and White, 1995). Thus, different doses of $\mathrm{H}_{2} \mathrm{O}_{2}$ were applied to investigate whether it is effective or not to control bacterial wilt of tomato plants (Fig. 3). The in vitro bacterial growths were initiated from two different doses $10^{5}$ and $10^{6} \mathrm{cfu} / \mathrm{ml}$ of liquid culture broth, and shown to be regulated by $\mathrm{H}_{2} \mathrm{O}_{2}$ dose-dependently (Fig. 3A). When the initial bacterial dose was $10^{5} \mathrm{cfu} / \mathrm{ml}$, bacterial growth was slightly arrested to ca. $85.9 \%$ by $0.0005 \mathrm{mM}$ of $\mathrm{H}_{2} \mathrm{O}_{2}$ and the reduced growth was maintained to $0.01 \mathrm{mM}$ of $\mathrm{H}_{2} \mathrm{O}_{2}$. Higher doses of 0.02 and $0.05 \mathrm{mM} \mathrm{H}_{2} \mathrm{O}_{2}$ decreased the growth to ca. 76.2 and ca. $33.8 \%$ compared to that of untreated control, respectively. No bacterial growth was found in the bacterial cultures treated with 0.1 and $0.2 \mathrm{mM}$ of $\mathrm{H}_{2} \mathrm{O}_{2}$. Initial bacterial inoculation concentration was increased to $10^{6} \mathrm{cfu} / \mathrm{ml}$ for the liquid cultures with or without $\mathrm{H}_{2} \mathrm{O}_{2}$ treatment. $\mathrm{H}_{2} \mathrm{O}_{2}$ induced bacterial growth reduction (ca. 89.7\%) first occurred by $0.002 \mathrm{mM} . \mathrm{H}_{2} \mathrm{O}_{2}$ dose of $0.005 \mathrm{mM}$ decreased the bacterial growth to ca. $80.9 \%$ and the bacterial reduction was continued to $0.02 \mathrm{mM}$. Higher doses of 0.05 and 0.1 $\mathrm{mM} \mathrm{H}_{2} \mathrm{O}_{2}$ decreased the growth to ca. 66.7 and ca. $4.7 \%$ compared to that of untreated control, respectively.

Higher concentration range of $\mathrm{H}_{2} \mathrm{O}_{2}$ was required for control of tomato bacterial wilt (Fig. 3B). By the inoculation with $R$. solanacearum suspension $\left(10^{6} \mathrm{cfu} / \mathrm{ml}\right), \mathrm{FW}$ of the detached leaves was significantly decreased to ca. $79 \%$ without $\mathrm{H}_{2} \mathrm{O}_{2}$ treatment at 3 days. One $\mathrm{mM}$ of $\mathrm{H}_{2} \mathrm{O}_{2}$ was ineffective to protect the tomato leaves. Higher than $2 \mathrm{mM}$ of $\mathrm{H}_{2} \mathrm{O}_{2}$ was evidently protective against tomato bacterial wilt, by which bacterial wilt was not found in the inoculated leaves at 3 days. Slight decrease of FW occurred in the detached leaves treated with $2 \mathrm{mM}$ of $\mathrm{H}_{2} \mathrm{O}_{2}$, but protective effect was still obvious even at 5 days after inoculation. Plant protection by more than $5 \mathrm{mM}$ of $\mathrm{H}_{2} \mathrm{O}_{2}$ was still distinguished at 5 days after inoculation.

$\mathrm{H}_{2} \mathrm{O}_{2}$ treatment was also effective to control tomato bacterial wilt caused by the inoculation with relatively higher dose of R. solanacearum suspension $\left(10^{7} \mathrm{cfu} / \mathrm{ml}\right)$. Two to five $\mathrm{mM}$ of $\mathrm{H}_{2} \mathrm{O}_{2}$ started to delay FW loss caused by the bacterial inoculation, and 5-10 $\mathrm{mM}$ range was the most effective for plant protection at 3 days after inoculation. However, 50$100 \mathrm{mM}$ of $\mathrm{H}_{2} \mathrm{O}_{2}$ rather reduced $\mathrm{FW}$ of detached leaves inoculated. Protective effect of $2 \mathrm{mM}$ of $\mathrm{H}_{2} \mathrm{O}_{2}$ at 3 days after inoculation diminished along with the disease progress at 5 days after inoculation. Higher than $5 \mathrm{mM}$ of $\mathrm{H}_{2} \mathrm{O}_{2}$ was still effective to control tomato bacterial wilt. 

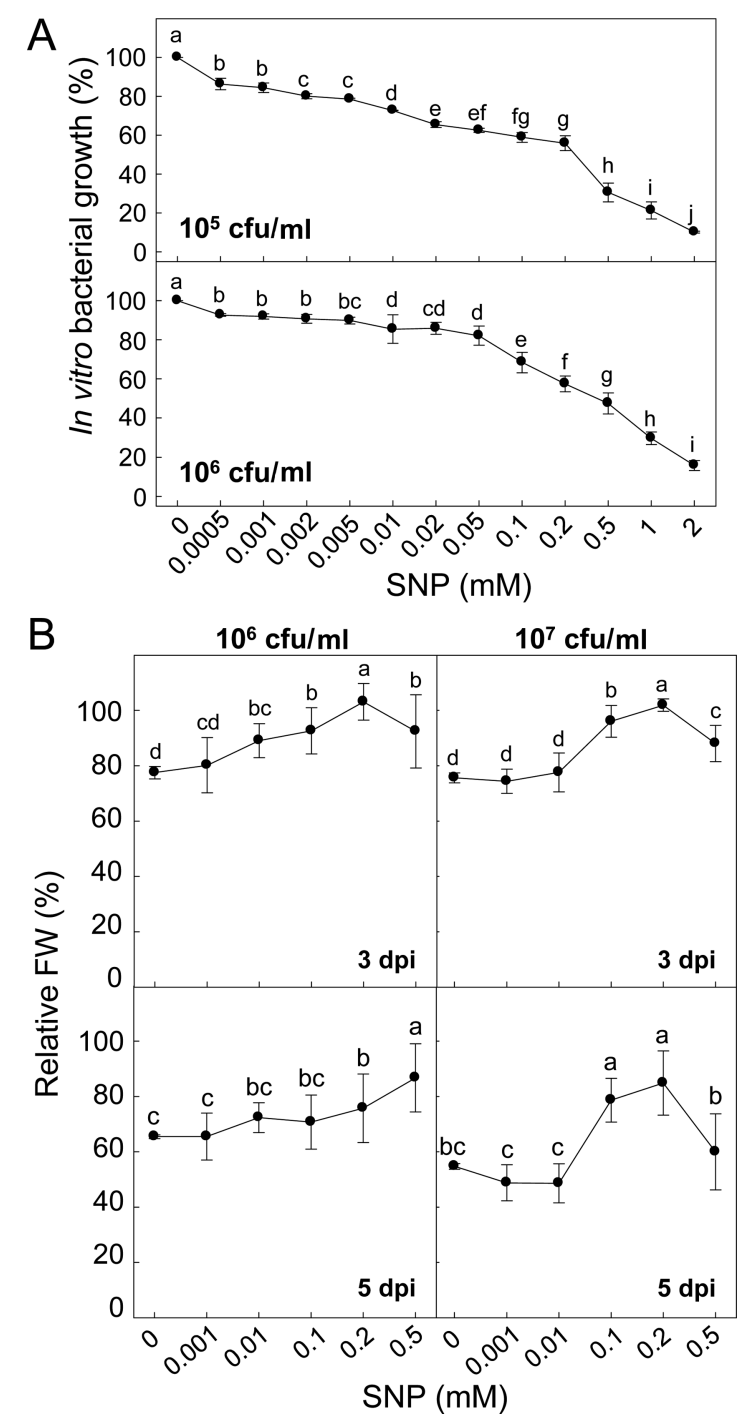

Fig. 4. Effect of sodium nitroprusside (SNP) nitric oxide releaser on Ralstonia solanacearum growth and bacterial wilt disease of detached tomato leaves. (A) In vitro bacterial growth of $R$. solanacearum in liquid cultures supplemented with different concentration of SNP. Initial inoculum doses for the bacterial cultures were shown in upper $\left(10^{5} \mathrm{cfu} / \mathrm{ml}\right)$ and lower $\left(10^{6} \mathrm{cfu} / \mathrm{ml}\right)$ graphs. Relative bacterial growth in response to SNP treatment was demonstrated as percentage (\%) compared to that in untreated bacterial culture. (B) Relative fresh weight (FW) of detached tomato leaves inoculated with two different $R$. solanacearum doses $\left(10^{6}\right.$ and $\left.10^{7} \mathrm{cfu} / \mathrm{ml}\right)$ in the absence or presence of SNP at 3 and 5 days post-inoculation (dpi). Independent experiments were performed 4 times with similar results. The data points are the mean $\mathrm{FW} \pm$ standard errors. Means followed by the same letter are not significantly different at $5 \%$ level by Duncan's multiple range test.

The effect of nitric oxide on $R$. solanacearum growth in vitro and tomato bacterial wilt control. The growth of $R$. solanacearum was also examined in vitro during liquid culture supplemented with different concentrations of SNP nitric oxide donor spectrophotometically (Fig. 4A). Two different initial bacterial numbers $\left(10^{5}\right.$ and $\left.10^{6} \mathrm{cfu} / \mathrm{ml}\right)$ were used. When the lower bacterial inoculum dose was $10^{5} \mathrm{cfu} /$ $\mathrm{ml}$, the bacterial growth was decreased to ca. $86.3 \%$ even at least $0.0005 \mathrm{mM}$ SNP treatment. Increasing SNP concentration gradually arrested the bacterial growth during its culture, and ca. $10.2 \%$ of bacterial growth was observed with $2 \mathrm{mM}$ supplement. When the relatively higher bacterial inoculum dose $\left(10^{6} \mathrm{cfu} / \mathrm{ml}\right)$ was cultured in the beginning, decrease of bacterial growth was more or less retarded. However, increasing SNP of more than $0.1 \mathrm{mM}$ also distinctly suppressed the bacterial growth.

To investigate the potential of SNP as a protection agent for tomato bacterial wilt control, tomato petiole dipping inoculation was performed (Fig. 4B). With a concentration of $0.001 \mathrm{mM}$, SNP could not provide disease control efficacy at 3 and 5 days after inoculation with $10^{6} \mathrm{cfu} / \mathrm{ml}$ bacterial dose. Treatment with higher than $0.01 \mathrm{mM}$ of SNP began to show protective effect against bacterial wilt, and the protection reached plateau at $0.2 \mathrm{mM}$. Higher SNP dose of 0.5 $\mathrm{mM}$ led to slight decrease of the FW of the detached leaves, presumably due to phytotoxic effect of high SNP dose. Low dose of SNP $0.1 \mathrm{mM}$ did not reduce disease severity at 5 days after inoculation, but disease protection was achieved by relatively higher SNP concentration of $0.2-0.5 \mathrm{mM}$. By the relatively higher bacterial inoculation $\left(10^{7} \mathrm{cfu} / \mathrm{ml}\right)$, protective effect of SNP slightly attenuated. At least higher than $0.1 \mathrm{mM}$ of SNP was effective to decrease wilting symptom at 3 and 5 days after inoculation. But $0.5 \mathrm{mM}$ of SNP rather decreased FW of the detached leaves.

Synergistic effect of $\mathrm{H}_{2} \mathrm{O}_{2}$ and nitric oxide on in vitro $R$. solanacearum growth and tomato bacterial wilt control. Accelerated cellular damages of $R$. solanacearum occurred by simultaneous treatment with different dose combinations of $\mathrm{H}_{2} \mathrm{O}_{2}$ and SNP when $10^{5}$ and $10^{6} \mathrm{cfu} / \mathrm{ml}$ of the bacterial doses for liquid culture was initiated (Fig. 5A). Bacterial culture began with $10^{5} \mathrm{cfu} / \mathrm{ml}$ was affected by different combinations of $\mathrm{H}_{2} \mathrm{O}_{2}$ and SNP. Increasing doses of SNP, $0.001,0.01,0.1$ and $1 \mathrm{mM}$, in the absence of $\mathrm{H}_{2} \mathrm{O}_{2}$, caused reduced bacterial growth showing ca. 91.1, 84.6, 67.7, $17.9 \%$, respectively, compared to that in untreated control culture. By $0.001 \mathrm{mM}$ of $\mathrm{H}_{2} \mathrm{O}_{2}$ alone, bacterial growth was slightly but significantly reduced to ca. $95.8 \%$ of the untreated control. However, treatment with increasing doses of SNP, 0.001, 0.01, 0.1 and $1 \mathrm{mM}$, in the presence of 0.001 $\mathrm{mM}$ of $\mathrm{H}_{2} \mathrm{O}_{2}$ did not alter the bacterial growth inhibition found in the bacterial cultures treated with different concentrations of SNP alone. By treatment with $0.01 \mathrm{mM}$ of $\mathrm{H}_{2} \mathrm{O}_{2}$, the bacterial growth much more arrested by $0.01-1$ $\mathrm{mM}$ of SNP was distinctly inhibited with ca. 74.5, 37.5 and $10.0 \%$ of relative growth, respectively. Higher dose of $\mathrm{H}_{2} \mathrm{O}_{2}$ 



Fig. 5. Protective effect of $\mathrm{H}_{2} \mathrm{O}_{2}$ and/or SNP on bacterial wilt disease of tomato seedling in pots. (A) In vitro synergistic bactericidal effect of $\mathrm{H}_{2} \mathrm{O}_{2}$ and SNP treatment on the growth of Ralstonia solanacearum in liquid cultures. Initial inoculum doses for the bacterial cultures were shown in upper $\left(10^{5} \mathrm{cfu} / \mathrm{ml}\right)$ and lower $\left(10^{6} \mathrm{cfu} / \mathrm{ml}\right)$ graphs. (B) Wilting symptoms of tomato plants in pots soil drench-inoculated by $R$. solanacearum in the presence or absence of $\mathrm{H}_{2} \mathrm{O}_{2}$, SNP and $\mathrm{H}_{2} \mathrm{O}_{2}+$ SNP treatment. Photo was taken 10 days after bacterial inoculation dpi, days post-inoculation. (C) Relative area under disease progress curve (AUDPC) used to evaluate tomato bacterial wilt by $R$. solanacearum for 14 days after soil-drench inoculation. Independent experiments were performed 4 times with similar results. The data points are the mean AUDPC \pm standard errors. Mean separation by Duncan's multiple range test at $P=0.05$. The same letter above bars represented no significant difference between treatments.

$(0.1 \mathrm{mM})$ completely suppressed the bacterial growth irrespective of SNP concentrations. Similar synergistic growth inhibition was also demonstrated in liquid cultures started with $10^{6} \mathrm{cfu} / \mathrm{ml}$. However, growth inhibitions by $\mathrm{H}_{2} \mathrm{O}_{2}$ and $/$ or SNP treatment was more or less lower than those found in liquid cultures initiated with $10^{5} \mathrm{cfu} / \mathrm{ml}$ of inoculum. Plant protection against the bacterial wilt by $\mathrm{H}_{2} \mathrm{O}_{2}$ and/or nitric oxide was evaluated using four-week-old tomato seedlings in pots (Fig. 5B and 5C). On the basis of results shown in Fig. 3 and Fig. 4, we selected $10 \mathrm{mM} \mathrm{H}_{2} \mathrm{O}_{2}$ and/or
$0.2 \mathrm{mM}$ SNP solutions were evenly applied just before bacterial suspension was soil-drenched in pots, and relative AUDPC was calculated based on disease severities evaluated daily for 2 weeks. Either $\mathrm{H}_{2} \mathrm{O}_{2}$ or SNP treatment alone in the soil mixture was not effective to suppress the bacterial wilt compared to disease severity of untreated plants. By contrast, $\mathrm{H}_{2} \mathrm{O}_{2}$ and $\mathrm{SNP}$ mixture significantly delayed disease development of tomato bacterial wilt.

\section{Discussion}

To reduce tomato bacterial wilt caused by $R$. solanacearum, various control methods have been applied in greenhouses and fields. Chemical pesticides have been suggested for a long time for soil sterilization before tomato planting or treatment during plant growth (Enfinger et al., 1979; Lee et al., 2012). Recently, antibacterial activity of different plant essential oils against $R$. solanacearum was demonstrated and it was applied to tomato plants against tomato bacterial wilt. Clove oil was most effective to decrease the disease severity of tomato bacterial wilt in our previous study (Lee et al., 2012). In this study, we observed accumulation of ROS in the tomato leaf tissues infected by $R$. solanacearum and evaluated the potential of $\mathrm{H}_{2} \mathrm{O}_{2}$ and nitric oxide for tomato bacterial wilt control.

Induced ROS generation has been well demonstrated in diverse plant-pathogen interactions (Lamb and Dixon, 1997). In general, rapid and strong oxidative burst during incompatible interaction contributed to hypersensitive cell death and disease resistance of host plants, whereas gradual and minute production of ROS in the plant tissues during compatible interaction did not attribute to disease resistance (Choi et al., 2007; Wang et al., 2007). Lipid peroxidation was also one of the hallmarks indicating cellular damage especially in membrane structure (Deighton et al., 1999; Jalloul et al., 2002). $\mathrm{H}_{2} \mathrm{O}_{2}$ accumulation and lipid peroxidation were differentially found in susceptible and resistant tomato cultivars inoculated by $R$. solanacearum (Mandal et al., 2011). Increase in $\mathrm{H}_{2} \mathrm{O}_{2}$ was much faster and stronger in the resistant response, whereas lipid peroxidation occurred much preferentially in the susceptible response. These indicated that $\mathrm{H}_{2} \mathrm{O}_{2}$ accumulation confers disease resistance of tomato plants against $R$. solanacearum. But dramatic increase of lipid peroxidation in the susceptible cultivar was cellular sign for plant membrane degeneration by disease progress. During bacterial pathogenesis in susceptible tomato cultivar by $R$. solanacearum, we confirmed the accumulation of ROS $\left(\mathrm{O}_{2}^{-}\right.$and $\left.\mathrm{H}_{2} \mathrm{O}_{2}\right)$ and the occurrence of lipid peroxidation histochemically in the tomato detached leaves of tomato during the susceptible response. ROS accumulation and lipid peroxidation were only found in the relatively late infection stage, at which plant leaf tissues were collapsed 
by the progressive infection and bacterial colonization. ROS contents in the infected susceptible plant tissues in this study may be not enough to hinder the bacterial proliferation, and thus, the invading bacteria can overcome the low level of ROS toxicity using their own antioxidant system. It led a notion that excessive ROS exogenously applied can disarm the bacterial antioxidant machinery and reduce tomato bacterial wilt symptom.

$\mathrm{H}_{2} \mathrm{O}_{2}$ treatment inhibited in vitro growth of various phytopathogenic bacteria ( $X$. campestris pv. vignicola), oomycete (P. tabacina) and fungi (B. cinerea, Cladosporium cucumerinum, Colletotrichum lagenarium, Rhizopus stolonifer, Penicillium digitatum and $P$. italicum) (El-Mougy et al., 2008; Kotchoni et al., 2007; Peng and Kuć, 1992). Mutants of Pseudomonas syringae pv. tomato and $X$. campestris pv. campestris which lost catalase-peroxidase KatG activity were more sensitive to even low levels of $\mathrm{H}_{2} \mathrm{O}_{2}$ than wildtype strains of the bacteria (Gou et al., 2012; Jittawuttipoka et al., 2009). Rice blast fungus Magnaporthe oryzae and citrus green mold $P$. digitatum established plant defenseinduced $\mathrm{H}_{2} \mathrm{O}_{2}$-detoxifying mechanism for self-protection and full virulence in their host plant tissues (Huang et al., 2011; Macarisin et al., 2007). To nullify $\mathrm{H}_{2} \mathrm{O}_{2}$-detoxifying ability of $R$. solanacearum, excess $\mathrm{H}_{2} \mathrm{O}_{2}$ was added during the bacterial culture in this study. $\mathrm{H}_{2} \mathrm{O}_{2}$ have shown in vitro antibacterial activity to $\mathrm{R}$. solanacearum in a dose-dependent manner, indicating it has the potential of bacterial wilt control in tomato plants. Indeed, a range of 5-100 $\mathrm{mM} \mathrm{H}_{2} \mathrm{O}_{2}$ could effectively reduce the bacterial wilt in the detached tomato leaves inoculated by the petiole dipping method (Fig. 3B). It was notably interesting that $\mathrm{H}_{2} \mathrm{O}_{2}$ concentration range effective to reduce bacterial wilt of the detached tomato leaves was remarkably higher than that for in vitro bacterial growth inhibition. Ineffective antibacterial activity of the low doses of $\mathrm{H}_{2} \mathrm{O}_{2}$ applied, enhanced bacterial growth and reduced plant protection efficiency can be mediated by unidentified host factors originated from petiole exudates of the detached tomato leaves. It is supported by the fact that a variety of $R$. solanacearum genes such as virulence genes pehR, vsrB and $h r c C$ have been specifically induced in tomato plants (Brown and Allen, 2004). These bacterial gene expressions might be activated by the tomato petiole exudates to evade or overcome oxidative stress condition by $\mathrm{H}_{2} \mathrm{O}_{2}$, which could let bacterial growth and virulence promoted but wilting symptom more progressed. Treatment with $10 \mathrm{mM}$ of $\mathrm{H}_{2} \mathrm{O}_{2}$ to detached tomato leaves by petiole feeding significantly protected the leaves to the bacterial invasion. However, the same dose of $\mathrm{H}_{2} \mathrm{O}_{2}$ soil-drenched in the pots was not effective to reduce the bacterial wilt symptom. It may be caused by insufficient contact between $\mathrm{H}_{2} \mathrm{O}_{2}$ and bacteria in the soil environment, or by different chemical compositions such as amino acids, organic acids and sugars of leaf petiole and root exudates (Kamilova et al., 2006; Lugtenberg et al., 1999).

High dose of nitric oxide may cause nitrosative stress in phytopathogenic bacteria (Erwinia chrysanthemi) and fungi (A. niger, B. cinerea, M. fructicola, $P$. expansum and $P$. italicum) as shown by reduced growths in vitro (Boccara et al., 2005; Lazar et al., 2008). Nitric oxide donor SNP treatment also suppressed $R$. solanacearum growth in vitro in this study, suggesting that SNP may reduce tomato bacterial wilt by direct antibacterial effect. Response of the detached tomato leaves treated with SNP without $R$. solanacearum inoculation was also examined. More than $0.5 \mathrm{mM}$ of SNP showed phytotoxic effect and significantly reduced plant growth of the detached leaves. SNP significantly decreased bacterial wilt in detached tomato leaves inoculated by petiole dipping. However, the $0.2 \mathrm{mM}$ of SNP was not enough for the protection against tomato bacterial wilt in pots with soil environments. It also may be derived from insufficient contact between SNP and the bacteria, or detoxification of SNP by the phytopathogenic bacteria in the soil mixtures.

Interestingly, treatment with $\mathrm{H}_{2} \mathrm{O}_{2}$ and SNP together significantly increased in vitro bactericidal activity as well as protective effect against bacterial wilt in tomato plants in the soil mixtures. Nitric oxide donor dithetylamine nitric oxide inhibited in vitro growth of Escherichia coli and accelerated $\mathrm{H}_{2} \mathrm{O}_{2}$-induced cell death of the bacteria, implying distinct cellular target proteins of $\mathrm{H}_{2} \mathrm{O}_{2}$ and nitric oxide in the bacteria (Brandes et al., 2007; Pacelli et al., 1995). $\mathrm{H}_{2} \mathrm{O}_{2}$ and SNP may exert their antibacterial activities against $R$. solanacearum via distinctly different mode-ofaction, which support the idea that $\mathrm{H}_{2} \mathrm{O}_{2}$ and SNP work together to suppress the bacterial growth of $R$. solanacearum and following tomato wilting synergistically. Activation of defense responses of tomato plants treated with $\mathrm{H}_{2} \mathrm{O}_{2}$ and/or SNP against $R$. solanacearum invasion remains investigated in further studies. The use of $\mathrm{H}_{2} \mathrm{O}_{2}$ and SNP together will be obviously useful in agricultural field for tomato protection against bacterial wilt through bactericidal activity and/or probable defense activation. Additionally, increases in dose of $\mathrm{H}_{2} \mathrm{O}_{2}$ and/or SNP without phytotoxic effects also remains to be evaluated in the tomato plants for the better protection efficiency against the bacterial wilt.

Taken together, both $\mathrm{H}_{2} \mathrm{O}_{2}$ and nitric oxide had direct bactericidal effects against $R$. solanacearum, which is one of the prominent activities to protect tomato plants against bacterial wilt. However, we cannot exclude the possibility that $\mathrm{H}_{2} \mathrm{O}_{2}$ and/or nitric oxide can be associated in the enhanced disease resistance to the tomato bacterial wilt by defense activating or priming in tomato plants, because it is evident that these two chemicals played roles as plant defense signal molecules in many plant species. Synergistic effect of $\mathrm{H}_{2} \mathrm{O}_{2}$ and nitric oxide for controlling tomato 
bacterial wilt may be applicable for other plant disease management. Application of $\mathrm{H}_{2} \mathrm{O}_{2}$ and nitric oxide together with other disease controlling agent like clove oil treatment shown in our previous study should be further considered for better integrated management of tomato bacterial wilt.

\section{Acknowledgements}

This research was financially supported by Export Promotion Technology Development Program, Ministry of Agriculture, Food and Rural Affairs, and by The Agricultural Genome Center (TAGC), in the Next-Generation BioGreen21 Program (grant no. PJ008211), Rural Development Administration, Republic of Korea.

\section{References}

Anith, K. N., Momol, M. T., Kloepper, J. W., Marios, J. J., Olson, S. M. and Jones, J. B. 2004. Efficacy of plant growth-promoting rhizocbacteria, acibenzolar-S-methyl, and soil amendment for integrated management of bacterial wilt on tomato. Plant Dis. 88:669-673.

Boccara, M., Mills, C. E., Zeier, J., Anzi, C., Lamb, C., Poole, R. K. and Delledonne, M. 2005. Flavohaemoglobin HmpX from Erwinia chrysanthemi confers nitrosative stress tolerance and affects plant hypersensitive reaction by intercepting nitric oxide produced by the host. Plant J. 43:226-237.

Bournonville, C. F. G. and Díaz-Ricci, J. C. 2011. Quantitative determination of superoxide in plant leaves using a modified NBT staining method. Phytochem. Anal. 22:268-271.

Brandes, N., Rinck, A., Leichert, L. I. and Jakob, U. 2007. Nitrosative stress treatment of $E$. coli targets distinct set of thiolcontaining proteins. Mol. Microbiol. 66:901-914.

Brown, D. G. and Allen, C. 2004. Ralstonia solanacearum genes induced during growth in tomato: an inside view of bacterial wilt. Mol. Microbiol. 53:1641-1660.

Byun, H.-J. and Choi, S.-J. 2004. Hydrogen peroxide induces resistance against anthracnose in cucumber (Cucumis sativus). J. Kor. Soc. Hort. Sci. 45:21-26.

Cerioni, L., Rapisarda, V. A., Hilal, M., Prado, F. E. and RodríguezMontelongo, L. 2009. Synergistic antifungal activity of sodium hypochlorite, hydrogen peroxide, and cupric sulfate against Penicillium digitatum. J. Food Protect. 72:1660-1665.

Choi, H. W., Kim, Y. J., Lee, S. C., Hong, J. K. and Hwang, B. K. 2007. Hydrogen peroxide generation by the pepper extracellular peroxidase $\mathrm{CaPO} 2$ activates local and systemic cell death and defense response to bacterial pathogens. Plant Physiol. 145:890-904.

Chun, H. J., Park, H. C., Koo, S. C., Lee, J. H., Park, C. Y., Choi, M. S., Kang, C. H., Baek, D., Cheong, Y. H., Yun, D.-J., Chung, W. S., Cho, M. J. and Kim, M. C. 2012. Constitutive expression of mammalian nitric oxide synthase in tobacco plants triggers disease resistance to pathogens. Mol. Cells 34:463-471.
Colburn-Clifford, J. M., Scherf, J. M. and Allen, C. 2010. Ralstonia solanacearum Dps contributes to oxidative stress tolerance and to colonization of and virulence on tomato plants. Appl. Environ. Microbiol. 76:7392-7399.

Deepak, S., Shailasree, S., Kini, R. K., Muck, A., Mithöfer, A. and Shetty, S. H. 2010. Hydroxyproline-rich proteins and plant defence. J. Phytopathol. 158:585-593.

Deighton, N., Muckenschnabel, I., Goodman, B. A. and Williamson, B. 1999. Lipid peroxidation and the oxidative burst associated with infection of Capsicum annuum by Botrytis cinerea. Plant J. 20:485-492.

El-Mougy, N. S., El-Gamal, N. G. and Abdalla, M. A. 2008. The use of fungicide alternatives for controlling postharvest decay of strawberry and orange fruits. J. Plant Protect. Res. 48:385395.

Enfinger, J. M., McCarter, S. M. and Jaworski, C. A. 1979. Evaluation of chemicals and application methods for control of bacterial wilt of tomato transplants. Phytopathology 69:637-640.

Flores-Cruz, Z. and Allen, C. 2009. Ralstonia solanacearum encounters an oxidative environment during tomato infection. Mol. Plant-Microbe Interact. 22:773-782.

Flores-Cruz, Z. and Allen, C. 2011. Necessity of OxyR for the hydrogen peroxide stress response and full virulence in Ralstonia solanacearum. Appl. Environ. Microbiol. 77:6426-6432.

Franks, A., Mark-Byrne, G. L., Dow, J. M. and O'Gara, F. 2008. A putative RNA-binding protein has a role in virulence in $\mathrm{Ral}$ stonia solanacearum GMI1000. Mol. Plant Pathol. 9:67-72.

Fu, L.-J., Shi, K., Gu, M., Zhou, Y.-H., Dong, D.-K., Liang, W.-S., Song, F.-M. and Yu, J.-Q. 2010. Systemic induction and role of mitochondrial alternative oxidase and nitric oxide in a compatible tomato-Tobacco mosaic virus interaction. Mol. PlantMicrobe Interact. 23:39-48.

Genin, S. 2010. Molecular traits controlling host range and adaptation to plants in Ralstonia solanacearum. New Phytol. 187:920-928.

Gou, M., Block, A., Bryan, C. D., Becker, D. F. and Alfano, J. R. 2012. Pseudomonas syringae catalases are collectively required for plant pathogenesis. J. Bacteriol. 194:5054-5056.

Guo, P., Cao, Y. , Li, Z. and Zhao, B. 2004. Role of endogenous nitric oxide burst in the resistance of wheat to stripe rust. Plant Cell Environ. 27:473-477.

Grant, M and Lamb, C. 2006. Systemic immunity. Curr. Opin. Plant Biol. 9:414-420.

Greenberg, J. T. and Yao, N. 2004. The role and regulation of programmed cell death in plant-pathogen interactions. Cell. Microbiol. 6:201-211.

Hafez, Y. M., Bacsó, R., Király, Z., Künstler, A. and Király, L. 2012. Up-regulation of antioxidants in tobacco by low concentrations of $\mathrm{H}_{2} \mathrm{O}_{2}$ suppresses necrotic disease symptoms. Phytopathology 102:848-856.

Hayward, A. C. 1991. Biology and epidemiology of bacterial wilt caused by Pseudomonas solanacearum. Annu. Rev. Phytopathol. 29:65-87.

Huang, K., Czymmek, K. J., Caplan, J. L., Sweigard, J. A. and Donofrio, N. M. 2011. HYR1-mediated detoxification of reactive oxygen species is required for full virulence in the rice 
blast fungus. PLoS Pathog. 7:e1001335.

Ishikawa, R., Fujimori, K. and Matsuura, K. 1996. Antibacterial activity of validamycin A against Pseudomonas solanacearum and its efficacy against tomato bacterial wilt. Ann. Phytopathol. Soc. Jpn. 62:478-482.

Jalloul, A., Montillet, J. L., Assigbetsé, K., Agnel, J. P., Delannoy, E., Triantaphylidés, C., Daniel, J. F., Marmey, P., Geiger, J. P. and Nicole, M. 2002. Lipid peroxidation in cotton: Xanthomonas interactions and the role of lipoxygenases during the hypersensitive reaction. Plant J. 32:1-12.

Ji, P., Momol, M. T., Olson, S. M., Pradhanang, P. M. and Jones, J. B. 2005. Evaluation of thymol as biofumigant for control of bacterial wilt of tomato under field conditions. Plant Dis. 89:497-500.

Jittawuttipoka, T., Buranajitpakorn, S., Vattanaviboon, P. and Mongkolsuk, S. 2009. The catalase-peroxidase KatG is required for virulence of Xanthomonas campestris pv. campestris in a host plant by providing protection against low levels of $\mathrm{H}_{2} \mathrm{O}_{2}$. J. Bacteriol. 191:7372-7377.

Kamilova, F., Kravchenko, L. V., Shaposhnikov, A. I., Azarova, T., Makarova, N. and Lugtenberg, B. 2006. Organic acids, sugars, and L-tryptophane in exudates of vegetables growing on stonewool and their effects on activities of rhizosphere bacteria. Mol. Plant-Microbe Interact. 19:250-256.

Koornneef, A. and Pieterse, C. M. J. 2008. Cross talk in defense signaling. Plant Physiol. 146:839-844.

Kotchoni, O. S., Torimiro, N. and Gachomo, E. W. 2007. Control of Xanthomonas campestris pv. vignicola in cowpea following seed and seedling treatment with hydrogen peroxide and Nheterocyclic pyridinium chlorochromate. J. Plant Pathol. 89:361-367.

Lai, T., Wang, Y., Li, B., Qin, G and Tian, S. 2011. Defense responses to tomato fruit to exogenous nitric oxide during postharvest storage. Postharvest Biol. Technol. 62:127-132.

Lamb, C. and Dixon, R. A. 1997. The oxidative burst in plant disease resistance. Annu. Rev. Plant Physiol. Plant Mol. Biol. 48:251-275.

Larsen, B. and White, S. 1995. Antifungal effect of hydrogen peroxide on catalase-producing strains of Candida spp.. Infect. Dis. Obstet. Gynecol. 3:73-78.

Lazar, E. E., Wills, R. B. H., Ho, B. T., Harris, A. M. and Spohr, L. J. 2008. Antifungal effect of gaseous nitric oxide on mycelium growth, sporulation and spore germination of the postharvest horticulture pathogens, Aspergillus niger, Monilinia fructicola and Penicllium italicum. Lett. Appl. Microbiol. 46:688-692.

Lee, Y. H., Choi, C. W., Kim, S. H., Yun, J. G., Chang, S. W., Kim, Y. S. and Hong, J. K. 2012. Chemical pesticides and plant essential oils for disease control of tomato bacterial wilt. Plant Pathol. J. 28:32-39.

Liu, P.-P., von Dahl, C. C., Park, S.-W. and Klessig, D. F. 2011. Interconnection between methyl salicylate and lipid-based long-distance signaling during the development of systemic acquired resistance in Arabidopsis and tobacco. Plant Physiol. 155:1762-1768.

Loprasert, S., Vattanaviboon, P., Praituan, W., Chamnongpol, S. and Mongkolsuk, S. 1996. Regulation of the oxidative stress protective enzymes, catalase and superoxide dismutase in Xanthomonas - A review. Gene 179:33-37.

Lugtenberg, B. J. J., Kravchenko, L. V. and Simons, M. 1999. Tomato seed and root exudates sugars: composition, utilization by Pseudomonas biocontrol strains and role in rhizosphere colonization. Environ. Microbiol. 1:439-446.

Macarisin, D., Cohen, L., Eick, A., Rafael, G., Belausov, E., Wisniewski, M. and Droby, S. 2007. Penicillium digitatum suppresses production of hydrogen peroxide in host tissue during infection of citrus fruit. Phytopathology 97:1491-1500.

Macho, A. P., Guidot, A., Barberis, P., Beuzón, C. R. and Genin, S. 2010. A competitive index assay identifies several Ralstonia solanacearum type III effectors mutant strains with reduced fitness in host plants. Mol. Plant-Microbe Interact. 23:1197-1205.

Mandal, S., Das, R. K. and Mishra, S. 2011. Differential occurrence of oxidative burst and antioxidative mechanism in compatible and incompatible interactions of Solanum lycopersicum and Ralstonia solanacearum. Plant Physiol. Biochem. 49:117-123.

Nakaune, M., Tsukazawa, K., Uga, H., Asamizu, E., Imanishi, S., Matsukura, C. and Ezura, H. 2012. Low sodium chloride priming increases seedling vigor and stress tolerance to Ralstonia solanacearum in tomato. Plant Biotechnol. 29:9-18.

Nguyen, M. T. and Ranamukhaarachichi, S. L. 2010. Soil-borne antagonists for biological control of bacterial wilt disease caused by Ralstonia solanacearum in tomato and pepper. $J$. Plant Pathol. 92:395-406.

Pacelli, R., Wink, D. A., Cook, J. A., Krishna, M. C., DeGraff, W., Friedman, N., Tsokos, M., Samuni, A. and Mitchell, J. B. 1995. Nitric oxide potentiates hydrogen peroxide-induced killing of Escherichia coli. J. Exp. Med. 182:1469-1479.

Park, K., Paul, D., Kim, Y. K., Nam, K. W., Lee, Y. K., Choi, H. W. and Lee, S. Y. 2007. Induced systemic resistance by Bacillus vallismortis EXTN-1 suppressed bacterial wilt in tomato caused by Ralstonia solanacearum. Plant Pathol. J. 23:22-25.

Peng, M. and Kuć, J. 1992. Peroxidase-generated hydrogen peroxide as a source of antifungal activity in vitro and on tobacco leaf disks. Phytopathology 82:696-699.

Pieterse, C. M. J., Leon-Reyes, A., van der Ent, S. and van Wees, S. C. M. 2009. Networking by small-molecule hormones in plant immunity. Nat. Chem. Biol. 5:308-316.

Saile, E., McGarvey, J. A., Schell, M. A. and Denny, T. P. 1997. Role of extracellular polysaccharide and endoglucanase in root invasion and colonization of tomato plants by Ralstonia solanacearum. Phytopathology 87:1264-1271.

Schell, M. A. 2000. Control of virulence and pathogenicity genes of Ralstonia solanacearum by an elaborate sensory network. Annu. Rev. Phytopathol. 38:263-292.

Thordal-Christensen, H., Zhang, Z., Wei, Y. and Collinge, D. B. 1997. Subcellular localization of $\mathrm{H}_{2} \mathrm{O}_{2}$ in plants: $\mathrm{H}_{2} \mathrm{O}_{2}$ accumulation in papillae and hypersensitive response during the barley-powdery mildew interaction. Plant J. 11:1187-1194.

Valls, M., Genin, S. and Boucher, C. 2006. Integrated regulation of the type III secretion system and other virulence determi- 
nants in Ralstonia solanacearum. PLoS Pathog. 2:e82.

van Loon, L. C., Rep, M. and Pieterse, C. M. J. 2006. Significance of inducible defense-related proteins in infected plants. Аnnu. Rev. Phytopathol. 44:135-162.

Wang, C.-F., Huang, L.-L., Buchenauer, H., Han, Q.-M., Zhang, H.-C. and Kang, Z.-S. 2007. Histochemical studies on the accumulation of reactive oxygen species $\left(\mathrm{O}_{2}^{-}\right.$and $\left.\mathrm{H}_{2} \mathrm{O}_{2}\right)$ in the incompatible and compatible interaction of wheat-Puccinia striiformis f. sp. tritici. Physiol. Mol. Plant Pathol. 71:230-
239.

Wang, Y.-S. and Yang, Z.-M. 2005. Nitric oxide reduces aluminum toxicity by preventing oxidative stress in the roots of Cassia tora L.. Plant Cell Physiol. 46:1915-1923.

Wang, Y., Yang, Q., Tosa, Y., Nakayashiki, H. and Mayama, S. 2005. Nitric oxide-overproducing transformants of Pseudomonas fluorescens with enhanced biocontrol of tomato bacterial wilt. J. Gen. Plant Pathol. 71:33-38. 